\title{
Interventionary Order and its Methodologies: The Relationship between Peace and Intervention
}

\author{
Oliver P. Richmond ${ }^{1}$ \\ Dept. of Politics, University of Manchester, UK. \\ College of International Studies, Kyung Hee University, Korea \\ Centre for Peace Studies, University of Tromso, Norway
}

\section{Funding}

The following grants supported this article: "The International Peacebuilding Architecture and State and Peace Formation in Post-Revolutionary Societies" and "Legitimacy and International Peacebuilding: Local Political Authority and Mobility" 2014-5 British Academy and University of Manchester; "Legitimacy and International Peacebuilding: Local Political Authority and Mobility", British Academy and University of Manchester 2017-19: EU Horizon 2020 funded project EUNPACK (grant no. 693337), 2016-19.

\section{Acknowledgements}

Thanks to several anonymous reviewers, and also to Sandra Pogodda and Gezim Visoka, for very insightful comments at various stages in the writing of the article. All errors are my responsibility alone. 
Keywords: Intervention, peacebuilding, nationalism, liberalism, everydayism

\begin{abstract}
Recently there have been calls from policymakers around the world for practically engaged research to produce evidence-based policy for peace, security, and development. Policymakers aim to align three types of methodological approaches to knowledge about peace, security and development in international order: methodological liberalism at state and international levels, aligned with 'methodological everydayism', in order to constrain methodological nationalism. Policy operates through broad forms of intervention, spanning military, governmental, and developmental processes, which scholarship is expected to refine. Critical scholarship is sensitive about the subsequent 'interventionary order', however, often connecting methodological everydayism with global justice frameworks rather than methodological nationalism or liberalism.
\end{abstract}

"Sir Philip Mitchell, later colonial governor of Uganda, Fiji, and Kenya, responded to Malinowski's claims [that the British government needed the support of Anthropologists] with great scepticism, emphatically expressing a preference for the "practical man" rather than the scientist.".

\title{
Introduction
}

Recent calls from elites and policymakers around the world for practically engaged research to produce evidence-based policy, for empirical and 'big-data' incursions into the 'local' and 'everyday', relate to a number of significant processes in contemporary international relations. They include constraining or facilitating military and humanitarian intervention, peace processes and peacebuilding, statebuilding, promoting human rights and democracy, or development and modernisation. They are often connected discursively to the goal of everyday and hybrid peace as a route to emancipation. The academy is required to support such goals by inventing new and useful disciplines (as with Anthropology, mentioned in the above epigraph) and recently through more interdisciplinary contributions.

Since the end of the Cold War, knowledge production in International Relations, peace and conflict studies, as well as in international policy settings, tends to focus on advancing methodological liberalism. ${ }^{3}$ This takes the form of both intervention and state governance. It aims to align with everyday practices and requires might be termed 'methodological everydayism, ${ }^{4}$ in order to constrain methodological nationalism as a historical force of disruption. $^{5}$ Thus, these three forms of methodology (liberalism, nationalism, and everydayism) are connected with different epistemological debates on the politics, interests, norms, and practices of intervention, requiring a knowledge base to support and legitimate them. They represent a methodological nexus of power, used to shape peace, security, development, and order in international relations, the state, and in everyday life.

This article examines how intervention is often presented as supporting a natural equilibrium for the states-system ${ }^{6}$ between power, interests, norms, justice, history, territorial 
units, and under both global governance and western hegemony. Sovereignty is its dominant narrative, disguising how global to local scale processes of intervention maintain a liberal international order. Often a 'far from equilibria' situation is put down to contextual, cultural, social, and historical deficiencies, maintaining unjust political systems. These in turn justify the further expansion of 'interventionary praxis', including knowledge production, through which intervenors refine their engagement with the other.

Along these lines, knowledge and methods are required for three sites of interventionary praxis: the liberal international, the state, and the social or everyday. This production of knowledge facilitates ever more refined forms of practical intervention to maintain and extend the existing order, rather than on settling subaltern claims for expanded rights and recognition. An 'interventionary order' has begun to replace the international order as a consequence of the growth of the praxis of intervention, drawing on the three main sites of knowledge production (the international, the state, and the everyday), producing requisite methodologies.

The article proceeds by exploring the links between power and intervention, order, and knowledge production that produce the interventionary system. It then outlines how this process is connected three main sites of praxis: methodological liberalism, nationalism, and everydayism. These are the most common sites of knowledge production and praxis in debates peace, security, and order, as well as for intervention. The article then turns to a discussion of interventionary praxis and its implications for critical thinking about peace.

\section{Intervention and Knowledge}

The increasing complexity of international order indicates that debates about peace, security, order and development tend to become platforms for the development of broad systems of intervention, rather than emancipation and global justice. Knowledge production is harnessed for intervention to preserve the international and states-system, rather than emancipation, often following the antecedents of the older dynamics of trusteeship and 'native administration'.

Critical scholars and practitioners in international relations, on the other hand, are often extremely sensitive about the risks of interventionary praxis, and yet depend on them to advance the cause of peace, security, rights and development. They often aim at surpassing the limits of the states-system and territorial sovereignty in doing so, ultimately by connecting knowledge drawn from liberal, national, and everyday methodologies with global justice. The three main methodological positionalities connected to peace, security, development and order, are thus often assumed to be closely aligned in order maintain their legitimacy and capacity: but in actual fact their relationality is more a function of power-relations, driven either methodological nationalism (as with the $19^{\text {th }}$ Century balance of power system), or if there is sufficient political will, methodological liberalism (as with the UN System after World War II).

Paradoxically, an 'interventionary order' offers emancipation from war violence, structural, and cultural violence. Yet, it also undermines sovereignty and subaltern claims for expanded rights beyond the limited set of basic, liberal human rights the international community offers. This contradiction means that the epistemic goals of human rights and democracy as advocated through the liberal international order since 1948 and 1990 respectively, of social and global justice in various critical academic literatures, are easily subverted. Instead they subsist within core-periphery frameworks of geopolitical and geoeconomic methodologies driven by methodological nationalism. This methodological positionality undermines the ethical basis of peacemaking activity by relating it to refinement of interventionary praxis, rather than rights or justice. 
These dynamics can be observed around three main sites of intervention and knowledge related to be peace and peacebuilding in international relations: methodological liberalism, which is aimed at constraining methodological nationalism, and in turn aims to represent the political claims found in methodological everydayism. The following sections outline these three methodologies of intervention.

\section{Methodological Nationalism}

Knowledge is a historic battleground for the struggle between the state, its order producing systems of intervention (internal and external), and knowledge. ${ }^{7}$ The state is paradigmatically disciplinary. All orders require ordering mechanisms that can deal with and recover from political shocks as well as discipline during unexceptional times. ${ }^{8}$ This is the point of the state, with either the goal of national interest at all costs, or national interest without disadvantaging others. Both depend upon power-relations and denote negative peace, meaning that peace, security and order depended on the balance of power. This helps explain why peace process such as that in Cyprus continue for decades: struggles over territorial sovereignty are difficult to resolve within the same zero-sum rationality, as the more recent example of the attempt to exchange territory in Kosovo also indicates. ${ }^{9}$

The post-Cold War liberal international order appeared to represent a complex confluence of science, pragmatism, and power aligning the international order with state and society. The framework of methodological nationalism privileged the state-based production of knowledge about domestic order, about other societies, and about the practices of intervention. ${ }^{10}$ This in turn has replicated the hierarchy of states in international order. It developed from state formation processes, soon betraying the inevitable limitations of the equation of peace with the balance of power in a state dominated, territorially sovereign order.

The sovereign approach to intervention, nested in methodological nationalism, saw intervention as an exception, designed to maintain hegemony or sovereignty. Intervention was directed at internal groups, other states, societies and empires where necessary and according to relative power and capacity, including in the production of knowledge. This methodology tended to equate academics as the servants of hegemony or imperialism whether at state or international level. ${ }^{11}$ The role of scholarship was to design, refine, and disguise intervention if necessary. This approach became necessary in a colonial framework, as well as in an era of total war and the failure of national boundaries to halt the spread of violence in the Twentieth Century. The conditions of the Cold War necessitated a more subtle approach to intervention, however, than the one that existed in the $19^{\text {th }}$ Century Realpolitik or colonial imaginations.

Methodological nationalism prioritised national interest and connected the production of knowledge and frameworks of intervention to maintain and stabilise a territorially sovereign order. This methodological phase of international order development offered a negative form of peace because of the inequalities and instability of power relations, mirrored in its crude appropriations of knowledge.

\section{Methodological Liberalism}

The response to the failure of methodological nationalism in a systemic sense of promoting peace and order was to try to design a global architecture based upon democratisation and human rights. This meant that broad forms of intervention could be designed following methodological liberalism, reflected in the post-war frameworks that emerged with multilateralism, the UN system, International Financial Institutions (IFIs) like the World Bank, 
regional actors like the EU, donors, and huge numbers of NGOs, among others. Peace from a liberal perspective appeared to involve international and local actors directing their combined energies on the state, minimalizing intervention to only when essential to maintain both the system and uphold human rights. The expansion of rights driven by subaltern claims also necessitated the expansion of the concept of intervention towards a framework that might be more associated with governmentality. ${ }^{12}$ This can be termed peace-as-governance, which has expansionary implications for intervention, even when associated with concepts like emancipation or justice. ${ }^{13}$

This methodological approach underlay the role of the UN and other actors in Bosnia, Cambodia, Kosovo, as well as many other post-Cold War cases, where human rights and democracy was seen to be a suitable response to the limitations of methodological nationalism. ${ }^{14}$ It was also significant in the Middle East and in Northern Ireland in the 1990s, with the former eventually reverting to methodological nationalism and the latter extending further into the terrain of methodological everydayism (of which more, below). ${ }^{15}$

In the liberal framework different forms of power and knowledge were to be aligned: power-to, as in Hobbes; ${ }^{16}$ power over, as in Weber; ${ }^{17}$ power despite resistance or power in concert as in Arendt; ${ }^{18}$ and power's potentiality, as in Lukes, ${ }^{19}$ were brought together. This led to a framework for a relatively benign and static state and international architecture based upon territorial sovereignty but domesticated by domestic and international liberal rights, which apparently minimised intervention and therefore maintained social and everyday legitimacy. Embedded in the state and international architecture, it required subtle forms of intervention travelling from western hegemony through international organisations, IFIs and donors, to the state, NGOs, and civil society, aligning them in a common framework of rights and democracy.

The European state was designed to simultaneous disrupt and improve or replace organic social order whilst also pacifying and representing it. ${ }^{20} \mathrm{By}$ the twentieth century, the project of pacification had extended to the 'liberal-international' and civil society then became essential for global rights under liberalism and essential for global markets under neoliberalism: both envisioned regulatory dependence upon but also resistance to the state. ${ }^{21}$ The production of knowledge about international order thus veered between facilitating intervention and protecting autonomy. Intervention as a broad ranging concept and practice thus became the inevitable partner of liberal and neoliberal notions of civil society, the associated state and international order. Yet, under the conditions of globalisation neither the state or the international has been able to mitigate material concerns in conflict-affected societies at anything more than a subsistence level. Critical scholarship has long pointed to this paradox, but peacebuilding, statebuilding, and development policy is driven by a neoliberal premise, as the long history of OECD, World Bank, IMF, and DFID's policies indicate. Mainstream scholarship disguises and refines the nature of intervention, in other words, under the terms of methodological liberalism, which became a form of liberal and neoliberal governmentality. ${ }^{22}$

This phenomenon has developed into a mix of liberal rights-oriented and neoliberal frameworks laid over the states-system and multi-lateral order. A framework for liberal intervention was authorised by the UN in the 'new wars' ${ }^{23}$ of the early $1990 \mathrm{~s}^{24}$ and advanced by the end of the decade ${ }^{25}$ to expand the concept of intervention in line with the requirements of relatively elastic concepts of peace, security, peacebuilding, and development, as well as genocide, war crimes, ethnic cleansing and crimes against humanity. This shift quickly began to foreground conceptions of rights and the everyday in what was otherwise envisioned as a liberal international system. Initially, intervention was aimed at producing a liberal peace- as in Bosnia, Timor Leste or Kosovo ${ }^{26}$ whilst overtly maintaining the norm of sovereignty, to which human rights would be subservient. ${ }^{27}$ However, it also encouraged policymakers to support subtler, 'programmatic' forms of intervention connected to development and 
modernisation, supporting or driving forward human rights. Rather than overt military or political control, these also related to security practices, the rule of law, human rights, democratisation and economic reform. They were centred on a peace agreement, security arrangements, constitutional reform, development and the engagement of civil society, such as with the Dayton Agreement for Bosnia Herzegovina in 1995, which seemed to revolve around a state apparatus, but in fact depended upon broad ranging forms of intervention.

The subsequent 'interventionary order' challenged the conceptualisation of peace connected to the states-system, the territorial state, its centralised powers, the fixed architecture of international system, and occasional intervention through peacekeeping, diplomacy, peacebuilding, or via donors and NGOs. Interventionary processes appear minimalist and conservative in that they aim at a limited version of peace and order, as say with the UN roles in the 1950s to the 1970s in the Middle East, Cyprus and the Democratic Republic of Congo. However, they also represent a direct challenge to long-entrenched power structures that maintain violence and inequality, ranging across the international and local political and economic order. Somewhat counter-intuitively, this helps explain significant resistance to UN peacekeeping and other unilateral forms of intervention, even when in the name of peace, security, and development.

These dynamics became even more problematic after Agenda for Peace reached doctrinal status in the late 1990s, and it became clear that the concept of peacebuilding would require more sophisticated forms of intervention to overcome powerful opposition from entrenched elites, as in the Balkans in the 1990s. The contradictions of ideological and normative over-extension, local resistance, and limited international resources and political will soon led- as with statebuilding projects in the mid 2000s in Iraq and Afghanistan- towards complex, neoliberal forms of reason and governmentality, ${ }^{28}$ drifting away from social and liberal understandings of government. These were heavily predicated on intervention aimed at both basic state security and the simultaneous production of resilient subjects. ${ }^{29}$ Consequently, through methodological liberalism, intervention had become a norm displacing sovereignty and rights as the basis for the production of order and peace. The production of knowledge refined ever more subtle frameworks of intervention to support both the stabilisation and advancement of a neoliberal order, without changing the existing political hierarchy of states. This contradicted the broad thrust of critical scholarship predicated upon uncovering injustice and inequality. ${ }^{30}$

This undermined the integrity of a fixed, territorial states-system where intervention is an exception related mainly to military engagements in war. Intervention became a broad ranging but disguised practice of governmentality, through which external actors use an underlying ethic of liberal peace to legitimate their various peace, security, and developmental projects. This triggered its use across a range of actors in the UN system, the donor system and global civil society. Thus, intervention has shifted from its liberal form to permanently governing the after-effects of structural forces in more neoliberal terms. Euphemistically, it was soon argued that subtle 'nudging' was the best that can be achieved in pragmatic terms. ${ }^{31}$

Consequently, the expansion of intervention supported by methodological liberalism had the additional consequence of undermining the authority of local actors. It led to local consensus about legitimate political authority being displaced by liberal or neoliberal, rationalities, supported by externalised tools and power. ${ }^{32}$ This process extended methodological liberalism to produce systems of intervention that operate beyond the realms of both the state and the international. Their neoliberal dimensions meant that they are also subtle enough to 'nudge' in order to avoid resistance, but they do not respond directly to the root causes of war and violence. Many of the recent programmatic aspects of peacebuilding, and global civil society networks, as well as donor engagements, might be seen in this light. 
Intervention is either exceptional but frequent under liberalism or a norm and camouflaged but constant under neoliberalism. The supposedly exceptional nature of intervention under a system of territorial sovereignty has thus increasingly been augmented by less visible approaches. It has shifted from the narrow, and visible, liberal exception to the camouflaged, regular, and broad neoliberal, norm. Both constitute the international order through a range of policy and knowledge frameworks, actor, practices, and institutions but underline its growing bifurcation around the quality and nature of order, and its relation to justice and peace.

It is here that a troubling divergence between liberal and critical methodologies have emerged. The broadening of interventionary praxis has displaced rather than augmented emancipatory thinking as a result. Intervention shapes the production of new knowledge about peace, security, development, and order because it is often rooted in hegemonic interests, in a post-1990 liberal-idealism, and a circa 2000's form of neoliberalism. It reifies liberal or state methodological approaches, aiming at the alignment of the everyday context and subaltern political claims with them, rather than meeting subaltern claims for emancipation at the everyday level.

\section{Methodological Everydayism}

Methodological nationalism and liberalism also require an engagement with everyday life, in order to protect national interests, to project human rights, to develop a social contract, and to maintain legitimacy and so political authority. They both require detailed knowledge about everyday life and politics, if intervention is to be effective, offering a relationship of compliance with state or external methodologies, producing hybridity, perhaps in a neotrusteeship framework (as in Kosovo after 1999), or autonomy (as in Somaliland to a larger degree). As with methodological nationalism and liberalism, the development of an epistemology of intervention is designed to solicit knowledge through an engagement with anthropology or sociology, often through ethnographic approaches, ${ }^{33}$ but within existing political, economic, and social structures and hegemony as determined by IR's focus on methodological nationalism or liberalism. This means its contribution to peace, justice, and order is limited to dominant interests in the international system rather than developing as a responsive engagement with subaltern claims as they emerge and expand in everyday life. Critical approaches to peace and conflict studies aim at achieving the latter, however.

Somewhat problematically, an uncritical and depoliticised version of the everyday is

often a starting point for a consideration of methodological everydayism. ${ }^{34}$ This is (often mistakenly) connected to early thinking about conflict transformation and resolution, and its development through the connection of everyday engagements of peace with social justice. Its influence has extended into later discussions about hybrid and everyday forms of peace, ${ }^{35}$ as well as discussions about custom and hybridity, ${ }^{36}$ care, empathy, and gender in international order. ${ }^{37}$

As in Northern Ireland, this enabled the alignment or bridging of the conflictual positions of international actors, state actors, and civil society actors. It complemented methodological liberalism, allowing for an embryonic, transversal and trans-scalar peace framework to emerge, in which sectarianism, everyday political claims, the interests of involved states (such as the UK and Ireland), and regional umbrellas such as the EU, could be mediated to a greater degree than ever before. ${ }^{38}$ Similar outcomes were also hoped for in Bosnia $^{39}$ but a misalignment between liberal peace, the state, and the everyday became a more accurate characterisation in which everyday peace took on a parallel political life and became 
subject, and even resistant, to intervention rather than aligned with broader notions of justice, as in Northern Ireland. ${ }^{40}$

The notion of civil society offers a starting point for methodological everydayism from a liberal perspective. Its role was to mediate emancipatory interests within the state, placing local knowledge and international architecture in a co-produced, interventionary relationship both focused on stabilising and improving the state ${ }^{41}$ through the liberal peace framework. An examination of the hierarchy of three bases for knowledge in modernity, including natural sciences and technical interests, historical-hermeneutic sciences and practical interest, and, finally, critical sciences and emancipation, ${ }^{42}$ indicate that everyday, subaltern claims are subject to the power relations between these knowledge bases. As agency and social transformation cannot be manufactured out of aspiration (or 'discourse'), but must also have a material framework, ${ }^{43}$ this means that civil society is either formative of the state or more likely is subject to its practical and scientific discipline, as Foucault outlined. Civil society, everyday peace and peace formation in this view, must either support methodological nationalism or liberalism or be resigned to making futile emancipatory and material claims. ${ }^{44}$ This means that any alliance between methodological everydayism, nationalism, and liberalism are likely to be hierarchical and antagonistic at best.

Thus, in practice, peace formation dynamics often contradict the goals of the state and international architecture. This can be seen in conflict-affected societies such as Kosovo where peace formation has been focused on self-determination and statebuilding: ${ }^{45}$ in Cyprus where it has been focused on ethnic co-existence and unification; and Timor-Leste where it has been focused on producing a historical and modern form of legitimacy for a liberal and hybrid form of state. ${ }^{46}$ Only in the case of Northern Ireland is there some sort of alignment, where rights and justice have been central, and the major nationalist and sectarian sources of conflict have been diminished by ambiguity over governance, territorial sovereignty, and political authority.

Peace formation highlights everyday emancipatory claims from an everyday, subaltern positionality targeted at both the state and the international community while addressing sociopolitical level conflicts. These claims may concur with liberal norms, especially with human rights and democracy, but they also fall outside of the dominate narratives of peacebuilding and statebuilding, enabling the state and the international architecture to block rather than to enable them. Peace formation claims may be material, structural, and ontologically different, compared to liberal-rights based claims because of differing modes of political community: for example, through custom, through religion, through patronage structures: or as in Kosovo for a secessionary state, in $\mathrm{BiH}$ for material improvement, and across the MENA region during the 'Arab Spring', for social advancement, rights, democracy and identity. Consequently, 'local knowledge' may challenge methodological nationalism, which connects to national interests and elite power, and methodological liberalism, which also relates to global hegemony.

Thus, methodological everydayism has quite different dynamics to nationalist and liberal versions in terms of the relationship between knowledge, power, and intervention. Connecting with either tends to result in its co-optation, but separation means it is relatively powerless even if this means it retains its normative integrity relating to micro epistemologies and methodologies. Ironically, scholars in diverse fields, point to long-standing evidence they have produced (often ignored by policymakers) about the obstacles to emancipation, indicating the over-riding need for critical research on subaltern claims and their blockages (which may emanate from methodological nationalism and liberalism). The concept of the subaltern thus offers a key critique from below of structural problems, as documented in a wide range of sources across disciplines. Such voices tend to argue that national or liberal-international policy is based upon a narrow standpoint supporting an unjust social and state hierarchy and suffers from international 'provincialism' in post-colonial terms ${ }^{47}$ from an everyday perspective. 
Subaltern claims in everyday methodological frameworks are highly politicised, and often aim to moderate or reform both national and liberal knowledge and interventionary praxis. Critical scholarship either seeks to map out the everyday in the context of adverse power-relations, or to engage with its subaltern claims against unaccountable power. The latter implies the expansion of rights beyond liberal understandings and represents a challenge to geo-political formulations of international and state power. Thus, methodological everydayism cannot be aligned with methodological nationalism or liberalism except through force or governmentality. Instead, it represents a radical challenge to scholarship aligned to state and liberal methodologies.

\section{From Practicality to Interventionary Knowledge}

What might be termed 'interventionary knowledge', driven by practical requirements, can therefore be organised around three main methodological approaches: methodological nationalism, where dominant interests drive interventionary practices and are derived from the states and states-system; methodological liberalism, in which liberal norms drive intervention from the international level for human rights and democracy or trade, as well as shaping domestic political interactions; and methodological everydayism, in which everyday practices, norms, and politics shape intervention and its critique from the perspective of emancipation and expanding rights.

All three are associated with different disciplinary areas: political science, political philosophy, IPE and IR, anthropology and sociology, respectively. All three versions have developed their own methods, norms, and aims. There has been an assumption that while they all remain normatively aligned with liberal peace then they will also be legitimate at the everyday level. They may then act as a check and a balance on the dynamics of violence in a state or region, thus reducing the negative impact of the imbalances caused by state and international power, influence and capacity, when measured against the claims and capacities of the conflict-affected everyday. However, it is also clear that the power relations between these different methodologies that underlie intervention means that the international and state levels are most significant, and the everyday can only offer claims against the state or the international when it has a strong alliance with one or the other: this means it is often co-opted. To alter this unequal epistemological relationship in order to reflect subaltern claims for expanded rights would involve deep structural change of the state and international system, indeed of methodological liberalism (and neoliberalism) and methodological nationalism. It is unfeasible to expect methodological everydayism to carry such weight without intervention.

The three methodologies claim epistemological support and ontological credibility, even though they contradict each other. In neoliberal terms, they are aligned by the goals of a secure state anchored in global governance, which provides the interventionary framework for the 'resilient subject' to prosper, but perhaps not for direct structural change related to rights and justice. Consequently, intervention itself has become a conservative but wide-spread practice aimed at mitigating the problems of the states-system, international order, and global capital, reflecting the power relations that exist between liberal, state, and everyday methodological positions. This is reflected in imitations of IMF and World Bank structural adjustment practices from the $1980 \mathrm{~s}^{48}$ in subsequent development, UN peacebuilding, statebuilding, R2P, donor and global civil society frameworks, and related interventionary practices. It is deeply rooted in the post-WW2 evolution of western economic and political hegemony and its extended engagement with its others. ${ }^{49}$ By taking this path it is closely related to older colonial practices and offers a choice between governmentality and justice, or an attempt to conflate the two with state or international governance. 
There is a long history behind the disdain of policymakers and practitioners for theory and scholarship that does not makes its practical value according to hegemonic goals clear. The 'practical man' is suspicious of what he may regard as complex theory, is focused on means, assumes the political debate over ends is settled, and is unconcerned about everyday social or historical context. This has left the liberal international order delegitimated, and even more dependent upon a wide range of interventionary practices, which in turn have become more and more politicised. The liberal international architecture has responded by calling upon scholars to assist them in expanding an interventionary system, driven by a bureaucratic, neoliberal and technological rationality. This has not bridged the different sources of legitimate authority (local, state, and international, political, social, or economic), as was originally envisioned in liberal discussions of social and international contracts, however. ${ }^{50}$ Knowledge production is part of the political process of global governance and its 'epistocracy'.51 Dominant assumptions about where the line is drawn between what is intervention and when it occurs, are supported by elite group-think, standard operating procedures, class and cultural commonalities amongst global policymakers and elites, and neoliberal ideological assumptions about the proper nature of social, economic, and political order, post-1945 and 1990. Thus, the concept of non-intervention is a theoretical cover for broader interventionary knowledge, for the purposes of peace, order, security and modernisation, which incidentally maintains historically produced inequalities through the 'rule of experts'. ${ }^{52}$

Power to remake international relations has thus become aligned with liberal and nationalist knowledge and their methods of intervention, from the local to the global. This alignment is sufficient to quell the reactions of subaltern subjects as well as to shape the state and control peace and security, as can be seen in the examples of intervention from $\mathrm{BiH}$ in 1995 to Iraq in 2004, in which international governance followed military intervention. ${ }^{53}$ Recently intervention has augmented insecurity with new types of biopolitical precarity because of its association with neoliberalism rather than human rights, making its legitimacy even more difficult to sustain. ${ }^{54}$ There is also now disagreement about the best international model of state for peace (sovereign, liberal democracy or authoritarian capitalist): whether remote and automated (i.e. built into less-than-sovereign states) forms of intervention are necessary to maintain them; and, if and how far local consent is required for contemporary legitimate authority. The logic of intervention is such that it appears to confirm the state, supported by external authority, legitimated elsewhere (the UN Security Council, the EU, state donors, INGOs, or the regional hegemon, for example). Increasingly states are the recipients of waves of intervention and social actors direct their agency at both the state and at formal interveners. A complex picture thus emerges of contemporary intervention and its associated methods and epistemologies. The 'practical man' referred to in the epigraph above, turns out to be the man (or woman) who does not question structural injustice. This illustrates how intervention as an evolving framework in international order has always been related to power and its epistemology and is currently related to global governance rather than global justice. ${ }^{55}$ Its disguise allows it to side step global justice's historical and distributive qualities. Making intervention a practical tool has made it central to international order, often against the grain of political legitimacy.

Thus, international governance, through the UN, donor, political and financial systems, has moved its focus from intervention as an exceptional event to long-term, but limited management from afar. Intervention is now constituted by international 'programming ${ }^{56}$ of the social and the state, through international agencies, development banks, donors, NGOs, and the military, utilising as much new technology as possible. ${ }^{57}$ It is led by core states and institutions. Applied research, at the apogee of the knowledge production chain, is essential for interventionary power and the order it seeks to produce. Scholarship and research are relegated to the secondary aims of the maintenance rather than transformation of the existing politico- 
ethical order, mediating the contradictory forces of security, territorial sovereignty and capital, rather than reflecting social claims for expanded rights. ${ }^{58}$

Intervention has become a norm for most liberal policy makers and many critical scholars, connected to the maintenance and slow improvement of domestic and international order, meaning methodological liberalism is its main driver. For a second, more conservative group it requires to geopolitical 'programming' as a form of global trusteeship and counterinsurgency, driven by methodological nationalism. For a third, post or anti-colonial group, rarely represented in global institutions or in knowledge production, intervention is a constant process of power relations that needs to be uncovered and challenged.

Basing intervention on practice, without an ethical framework for understanding the goals or order it produces, has led to a situation where practical scholarship across a range of disciplines is deflected from the great political and justice questions of peaceful order. This supports sovereign and structural power, which are often combined directly under contemporary globalisation and global governance to make the claim that deeper structural reform is impossible (and indeed unnatural). ${ }^{59}$ The interventionary system means that deeper structural change- as might be demanded by the global justice rationality that emerges from a subaltern perspective- can be avoided through constant interventions which nudge the current system along, but which also blocks everyday aspirations for global justice. This undermines its social legitimacy. ${ }^{60}$ Expert knowledge is essential for aligned, scalar systems of governmentality, from 'local ownership' to 'decentralisation', neoliberal statebuilding, and regional normative, soft, and global power. ${ }^{61}$ It points to an underlying premise that societies need to accept their current structural situation (i.e. in geopolitical, geo-economic, human development, and so global justice, terms). Thus, peacebuilding and development might be called 'resilience training': conflict-affected subjects are expected to restrain their own political expectations while political, economic, and social reforms are guided by external actors (such as the UN, the IFIs, donors, or NGOs) heavily influenced by methodological liberalism or nationalism.

This is all problematic because historical and distributive, global justice issues have not been solved. Emancipatory and evidence-based calls from scholars, from within social movements, and many other organisations worldwide, desire knowledge to be used to enable intervention into the broad power-structures that block social emancipation on a world-wide scale. ${ }^{62}$ Power-relations in this sense are a contest of geopolitics and geo-economics (i.e. direct, structural and governmental power) against a Foucauldian field of (subaltern) everyday social forces. ${ }^{63}$ These positions relate respectively to peace as a realist balance of power, where intervention is limited to just-war positions because peace and order are very basic: liberal peace where rights, humanitarian, developmental, peacebuilding, statebuilding and $\mathrm{R} 2 \mathrm{P}$ positions on intervention inevitably emerge; and critical positions pointing to the materiality of inequality, and social justice. The latter points to hybridity, mobility, networks, environmentalism, and global justice (historical and distributive) as the basis for peace. ${ }^{64}$ This shifts the nexus of peace from geopolitics, democracy, law and institutions, nudging and broad processes of intervention, following the path of methodological liberalism and nationalism, towards global justice following the path of the methodological everyday.

Yet, pragmatic policymakers tend to see critical scholars as engaging in counterconduct if they develop methodological everydayism. Critical scholars in turn tend to respond to the forces of eternal sovereignty or capital by pointing to medium- and long-term problems of instability, to normative matters related to rights, inequality, environmentalism, and identity, and related questions of viable progress ${ }^{65}$ supported by methodological nationalism and liberalism. This is expressed as a powerful critique of various high-level projects for a peace settlement such as in Cyprus, and peacebuilding and state building, as in Kosovo and Timor. ${ }^{66}$ Another problem arises in the context of southern knowledge. ${ }^{67}$ Power in these terms has been 
translated into knowledge associated with the control of methodological nationalism and capture of methodological everydayism by methodological liberalism.

Since 1989 social claims for intervention have challenged elite, state, and international power-structures, while programmatic forms of intervention have in turn challenged social claims for justice. Thus, nationalist, state-centric knowledge in IR is inevitably counterinsurgency knowledge (i.e. methodological nationalism), which aims at disrupting civil society and its control through liberal governmentality, corralling knowledge production in the process. ${ }^{68}$ This prevents counter-conduct and emancipatory agency from crossing over from discourse into praxis. ${ }^{69}$

\section{Reconceptualising Intervention}

Narrowly defined, intervention is thus normally understood in the context of fixed sovereignty and geopolitics (methodological nationalism), extended into liberal terrains by UN peacebuilding and R2P-type doctrines (methodological liberalism). Intervention, knowledge and peace and order are state driven. Thus, emancipation can be effectively redefined as selfhelp and resilience, where intervention nudges subtly through capitalist rationalities. More broadly defined, intervention may be understood to have emancipatory goals (methodological liberalism) within the confines of liberal rationality, which has also driven forward methodological everydayism, which aims to transcend the limits of sovereignty and the international normative order in order to advance a global justice framework. ${ }^{70}$ It thus may span a broad range of practices, from the military to the economic, and social. Short term and long-term perspectives differ in the context of structural change: that is, not only maintaining the system according to hegemonic intent, but also improving it according to subaltern claims and knowledge about justice and sustainability.

Critical scholarship illustrates that seeing a static view of the international order makes practices of intervention appear to be occasional, necessary, and considered. ${ }^{71}$ They appear to represent an exercise of power to preserve the state or international architecture, and where this is not possible to reduce conflict to a minimum, preventing the need for structural change. ${ }^{72}$ Liberal methodology in its Kantian form, ${ }^{73}$ provides the intellectual framework in which this is reconciled, whether through blue-print driven standard operating procedures and pathway dependency, or through reforms, new policy shifts, and so on. Foucault made this clear in his work on the intimate and obscure relationship between knowledge and (capillary) power. ${ }^{74}$ Thus, most mainstream research and related government policy are designed to make the subaltern fit into its interventionary paradigms, rather than to take account of its expanding claims. ${ }^{75}$ It generally rejects local voices and critical scholarship as impractical or 'radical', it cannot engage properly with networks, mobility, or vertical, and transversal relationships, or claims, when they are not couched within the liberal or national system or defer to its hierarchies. Nor can it comprehend the constitutive nature of ongoing interventionary practices. Evidence-based research and policy simply recycle the causal factors of conflict and structural violence under the current hegemony as if it was homeostatic. They reiterate its fixity and attempt to sharpen its visible and invisible tools of intervention. ${ }^{76}$ They cannot engage with the entwined and complex agency that emerges through methodological everydayism. ${ }^{77}$ Such epistemological revisions require methodological and ontological alterations. This cannot be achieved by 'practical men', for whom intervention is a conservative rather than critical force. Critical scholars are often unwilling to risk being tainted by interventionary praxis, but clearly, they refer, partly through the subaltern, to a historical, disciplinary, and ethical store of knowledge on a broad scale: they are often connected to local actors who make subaltern claims against, or on behalf, of the interventionary system. 
Through a critical epistemology, as emerges via methodological everydayism, intervention is perceived as a norm which is ambiguous about the way sovereignty and international architecture may maintain injustice and block global justice to overcome historical power-relations. The emergence of a range of tools and programmes to maintain and repair order (such as statebuilding and good governance programmes, peacekeeping, peacebuilding, donors, civil society, and development) make this plausible. It also explains the historical layers of intervention that have shaped the modern state or regional system in the Middle East or Sub-Saharan Africa, for example. ${ }^{78}$ Concepts such as development, R2P, democratisation, and peacebuilding are the open expression of this underlying dynamic. Critical scholarship has long argued that higher-level states in the UNDP Global Development Index and the geopolitical hierarchy practice intervention as a constant on lower states. Most international programming actors, including transnational actors, are agents of dominant states, within the framing of the modern 'Anglo-sphere'79 and Euro-centric thought on modernization. Methodological everydayism has uncovered how the states-system, the international system, regionalisation, and global capital increasingly require forms of knowledge (realism, rational-legal-institutionalism, integration, neoliberalism) that can smooth out their internal inconsistencies. Thus, the aims of peacebuilding, statebuilding, development, and recent stabilisation policies ${ }^{80}$ are to utilise practical and theoretical knowledge to produce such forms of continuous intervention in a shifting, networked, and multi-scalar framework. ${ }^{81}$

Somewhat ironically, an interventionary epistemology resists global justice while claiming to be vital for emancipation. It simultaneously rejects non-elite, non-western, participatory and democratic demands for historical and distributive justice and deeper structural reform. Yet, methodological everydayism provided the platform for human rights and democracy in the Twentieth Century and the subtext of the Sustainable Development Goals more recently. It has facilitated a connection between emancipatory knowledge and structural change, making wider claims for emancipation within the praxis of intervention. ${ }^{82}$

This explains in part Foucault's biopolitical and governmentality approaches and connects them directly to the networked agency and capillary power now commonly thought of in the context of civil society, the state, and a range of transnational organisations. ${ }^{83}$ An interventionary system works through layers of governmentality, from local to global. This would also explain the circulation of power and norms, the complicated networks of global governance, the possibility of local resistance, and a whole range of assumptions about emergent fluid, relational dynamics even in the midst of eternal sovereignty and international architecture. ${ }^{84}$ It helps unravel the palimpsest layers of the international system, which have been based upon some fixed core states, intervention, and a fluid periphery. ${ }^{85}$ Methodological everydayism draws on a mix of personal sovereignty, relationality, networks, and growing agency and 'ungovernmentality', ${ }^{86}$ promoting scalar and spatial, transversal and transnational mobility utilising enormous amounts of information. ${ }^{87}$ This represents an emerging agenda for peace, connected to global justice in the $21^{\text {st }}$ Century, and inevitably also partly conducted through new types of intervention.

\section{Conclusion}

"Expert rule mobilises knowledge as power." 88

Scholarship that is focused on a dealing with the inconsistencies outlined above tend to point to the following five elements:

(i) the balance between global capital, political, social, and economic rights: 
(ii) identity and pluralism;

(iii) environmental sustainability;

(iv) Global (historical, distributive, gender and environmental) justice;

(v) mobility, scale, and networks.

These five points indicate that waves of intervention, both conservative and progressive, move along networks related to power, knowledge, rights, justice and mobility, across scales, levels, and borders. Thus, peace, security, and related praxis has to engage with much bigger questions of global justice. ${ }^{89}$ One the one hand, intervention carries its own ideological stances, points to groupthink and SOPs, supports institutional frameworks, and professional and national advantages. On the other hand, critical engagement with intervention can deflect the development of trusteeship or 'native administration' type accompaniments and amplify the critiques of the subaltern aimed at epistemic power-relations, expanding political claims for rights, and their understanding of the need for interventionary support. ${ }^{90}$ Thus, more relational and multi-dimensional methods and epistemologies are required. ${ }^{91}$

The liberal international order has been the most successful peace architecture ever, and methodological liberalism has met the challenge of methodological nationalism by establishing a complex system of intervention as a nexus of power that could tame geopolitics, imperialism, and civil war. The "international order" has thus become interventionary rather than noninterventionary- a legal fiction at best, ${ }^{92}$ and the peace it has produced is uneven and fragile when viewed from the perspective of methodological everydayism. Subaltern views of power and intervention as being formative of political order point to far broader issues of global justice as a consequence. ${ }^{93}$

There is no escaping the complex logic of the interventionary order: undoing it is to risk war, ${ }^{94}$ but accepting it requires ever more complex and sophisticated checks and balances, to make sure that conflict-affected polities build legitimacy and order in the context of global justice rather than geo-political interests. As the critical peace debates advance towards a closer connection with global justice, they may also be more dependent on broad and complex systems and practices of intervention, producing a paradox that threatens the legitimacy of the concept of peace itself. ${ }^{95}$ This explains the recent shift from methodological liberalism to everyday, micro-level frameworks, with its potential and its risks. The interventionknowledge- peace nexus has driven scholarship towards supporting what Foucault called the 'reason of least state' in which civil society plays a vital role as a check and balance on despotism, ${ }^{96}$ requiring global and benign hegemony to support them. Nevertheless, the international community has stepped back from supporting social peace or global justice, instead relying on power-sharing frameworks (e.g. illiberal states as in Cambodia or Bosnia). Thus, peacebuilding praxis, rather than meet the challenge of methodological everydayism, has engaged with neoliberal rationalities, which in turn have driven it back to methodological nationalism.

In historical terms, the evolution of methodologies of intervention might be seen as first an attempt at the direct control of others through imperialism and colonialism: then the dissemination of similar state forms through decolonisation, peace processes, peacekeeping, peacebuilding and statebuilding, as could be seen in the 1990s in Bosnia and Kosovo; and then the refinement- and failure- of interventionary practices to reinforce or maintain liberal or neoliberal control as occurred in the 2000s in Afghanistan. It has attracted new technologies of power, ironically aimed more at containment as in Libya or Syria. Each step along this path seems to undermine the ethical basis of peacebuilding, but also to amplify the need to connect them with developing post-colonial conceptions of global justice. ${ }^{97}$ This implies the advancement of relational ontology as the basis an emancipatory peace, security and order in view of broad conceptions of intervention related to mobility, networks, transversality, and 
related types of agency. No power is constructed or exercised without its entangled oppositions. No agency survives without entanglement in other agencies and their complexity. ${ }^{98}$ Thus, peace represents a long process of mutual and entangled interventions, agencies, networks and mobilities, discursive and structural, offering some potential for a more emancipatory form.

\section{References}

Acemoglu, Daron, and James A Robinson. Why Nations Fail, London: Profile 2012.

Arendt, H, Eichmann in Jerusalem: A Report on the Banality of Evil, Penguin Classics, 2006 [1963].

Arendt, Hannah. On Violence. New York: Harcourt, 1970.

Arendt, Hannah. The Origins of Totalitarianism, New York, Harcourt Brace, 1951.

Behavioural Insights Team, Better Choices: Better Deals, London: UK Cabinet Office 2012.

Bell, Duncan (2014) "What is Liberalism?" Political Theory, 42, no. 6, (2014).

Bhaskar, R. The Possibility of Naturalism, New York: Harvester Wheatsheaf, 1989.

Boege, Volker, M. Anne Brown \& Kevin P. Clements "Hybrid Political Orders, Not Fragile States". Peace Review, Feb, (2009): 13-21.

Boutros Boutros-Ghali, An Agenda for Peace. UN, 1994.

Branka Marijan "The politics of everyday peace in Bosnia and Herzegovina and Northern Ireland", Peacebuilding, (5) No. 1, 2017: 67-81

Caplan, R A New Trusteeship?: The International Administration of War-torn Territories, Taylor \& Francis. Routledge 2002.

Chandler, David 'Beyond neoliberalism: resilience, the new art of governing complexity', Resilience: International Policies, Practices and Discourses, (2) No.1: 2014: 47-63.

Chandler, David Bosnia: Faking Democracy After Dayton London: Pluto Press, 1999.

Chandler, David International Statebuilding: The Rise of Post-Liberal Governance

Routledge, 2010.

Chandler, David, Ontopolitics and the Anthropocene, London: Routledge, 2018.

Chandler, David. "Reconceptualising International Intervention: Statebuilding, 'Organic Processes' and the Limits of Causal Knowledge", Journal of Intervention and Statebuilding, (9) No.2, 2015.

Chandler, David. Resilience, the Governing of Complexity, London: Routledge, 2015.

Chomsky, Noam. "The Responsibility of Intellectuals", The New York Review of Books, February 23, 1967.

Comaroff, Jean and John L. Comaroff. Theory from the South or, How Euro-America Is Evolving toward Africa, Boulder, CO: Paradigm Publishers, 2012.

Connolly William A. Facing the Planetary, Durham: Duke University Press, 2017.

Coole, Diana, and Samantha Frost, eds. New Materialisms: Ontology, Agency, and Politics, Durham, NC and London: Duke U P, 2010.

DeGooyer S (et al) eds., The Right to Have Rights, London: Verso, 2018.

Dipesh Chakrabarty Provincializing Europe: Postcolonial Thought and Historical Difference, Princeton University Press, 2000.

Duffield, Mark Post-Humanitarianism, Cambridge: Polity, 2018.

Duffield, Mark. Global Governance and the New Wars: The Merging of Development and Security, London: Zed Books, 2001.

Estlund, D. "Why not Epistocracy?" In N. Reshotko (ed.). Desire, Identity and Existence. Essays in Honor of T. M. Penner. Kelowna, B.C.: Academic Printing \& Publishing, 2003, pp. 53-69.

Finnemore, Martha. The Purpose of Intervention, Changing Beliefs about the Use of Force, Cornell University Press, 2003. 
Foucault, Michel. Discipline and Punish: the birth of a prison, London, Penguin, 1991. Foucault, Michel (2007). Security, Territory, Population, London: Palgrave.

Foucault, Michel. The Birth of Biopolitics, London: Palgrave, 2008.

Foucault, Michel. "Questions of Method", in Graham Burchell et al (eds.), The Foucault Effect, London: Harvester Wheatsheaf, 1992.

Graham Burchell, Colin Gordon and Peter Miller (eds) The Foucault Effect: Studies in

Governmentality, Chicago, IL: University of Chicago Press: 87-104.

Grenfell, D. "Making modernity in Timor-Leste". Arena Magazine, 90, (2007).

Habermas, J Knowledge and Human Interests, 1968.

Habermas, J The Structural Transformation of the Public Sphere. 1962.

Hadjipavlou, M. "The Cyprus Conflict: Root Causes and Implications for Peacebuilding".

Journal of Peace Research, (44) No.3, (2007): 349-365.

Hall, A "Incomplete Peace and Social Stagnation: Shortcomings of the Good Friday

Agreement". Open Library of Humanities, (4) No.2 (2018): 1-31.

Hallaq, Wael B. The Impossible State, Columbia University Press, 2013.

Held, David Global Covenant, Cambridge, Polity Press, 2004.

Hobbes, T, Leviathan, Penguin, 1985 [1651].

Hurrell, Andrew. "Global Inequality and International Institutions." In Thomas Pogge (ed.), Global Justice. Blackwell: Oxford, 2001.

International Commission on Intervention and State Sovereignty, "The Responsibility to Protect: Report of the International Commission on Intervention and State Sovereignty" December 2001.

James, Paul and Soguk, Nevzat. Globalization and Politics, Vol. 1: Global Political and Legal Governance, London: Sage Publications, 2014.

Joseph, Joseph S “Governing Through Failure and Denial: The New Resilience Agenda" Draft Paper, 2015.

Kaldor, Mary New and Old Wars. Cambridge: Polity Press, 1999.

Kaldor, Mary. Global Civil Society: An Answer to War, Oxford: Polity, 2003.

Kant, I, Conflict of the Faculties University of Nebraska Press, 1992 [1798].

Kennedy, David. A World of Struggle, Princeton University Press, 2016.

Ker-Lindsay, J., EU Accession and UN Peacemaking in Cyprus, London: Palgrave, 2005.

Kohn, Margaret "Postcolonialism and global justice", Journal of Global Ethics, (9) No.2, 2013: 187-200.

Latour, B. Reassembling the Social: An Introduction to Actor-Network-Theory, Oxford: Oxford UP, 2005.

Lederach John Paul, (1996) Preparing for Peace: Conflict Transformation Across Culture,

Syracuse University Press.

Lensink, R. Structural adjustment in Sub-Saharan Africa, Longman, 1996.

Lewis, HS. In Defense of Anthropology, New Brunswick: Transaction Publishers 2014.

Linklater, Andrew. 'The achievements of critical theory', in Booth, Ken, Smith, Steve \& Zalewski, Marysia, eds, International Theory: Positivism and Beyond, Cambridge: Cambridge University Press, 1996.

Linklater, Andrew. 'The transformation of political community: E.H.Carr, critical theory and international relations', Review of International Studies, (23), 1997: 321-338.

Lukes, S . Power: A Radical View, Palgrave. 2005 [1970].

Mac Ginty, R "Everyday peace: Bottom-up and local agency in conflict-affected societies" Security Dialogue, 45, No. 6 (December) (2014) 548-564

Marsha Henry "Gender, security and development", Conflict, Security \& Development, (7) No.1, (2007): 61-84 
Mayall, James. Nationalism and international society Cambridge: Cambridge University Press, 1993

Mayer, M, and M Acuto. "The Global Governance of Large Technical Systems", Millennium, (43) No.2. (2015).

Millar, Gearoid. "Engaging Ethnographic Peace Research: Exploring an Approach",

Mitchell, Timothy. Rule of Experts: Egypt, Techno-Politics, Modernity, Berkeley, CA: The University of California Press, 2002.

Nixon, R. "The crisis of governance in new subsistence states" Journal of Contemporary

Asia, 36, No,1 (2006).

Paris, R At War's End, Cambridge University Press, 2004.

Pattberg, Philipp and Oscar Widerberg. "Theorising Global Environmental Governance", Millennium, (43) No. 2, 2015.

Peo, Sorpong "Peace through Democracy and Justice? Legacies and Lessons from the Case of Cambodia." The Asian Journal of Peacebuilding 5 no.1. (May) (2001) 89-110.

Pogge, Thomas. World Poverty and Human Rights, Cambridge: Polity, 2002.

Pogodda, Sandra and Oliver P. Richmond. "Palestinian unity and everyday state formation: subaltern 'ungovernmentality' versus elite interests", Third World Quarterly, (36) No.5 (2015): 890-907.

Pugh, Michael (2004). "Peacekeeping and Critical Theory", International Peacekeeping, 11 no.1 (2004): 39-58.

Pyykkonen, Mikka. "Liberalism, Governmentality and Counter-Conduct", Foucault Studies, No.20 (2015).

Rawls, John. A Theory of Justice, Harvard University Press, 1971

Reed, M, and David L Harvey, "The New Science and the Old: Complexity and Realism in the Social Sciences", Journal for the Theory of Social Behaviour, 22 no.4 (1992).

Reus-Smit, Christian. Individual Rights and the Making of the International System, Cambridge University Press, 2013.

Richmond Oliver P, Human rights and the development of a twenty-first century peace architecture: unintended consequences?, Australian Journal of International Affairs, (73)

No.1, 2019: 45-63

Richmond, Oliver P, Stefanie Kappler \& Annika Björkdahl (2015). "The 'Field' in the 'Age of Intervention': Power, legitimacy, and authority versus the local" Millennium, 44 (2).

Richmond, Oliver P \& Jason Franks, Liberal Peace Transitions, Edinburgh University Press, 2009.

Richmond, Oliver P The Transformation of Peace, London: Palgrave, 2005.

Richmond, Oliver P, "A Post-Liberal Peace: Eirenism and the Everyday", Review of International Studies, 35, (2009) pp.557-580.

Richmond, Oliver P, "The paradox of peace and power: Contamination or enablement?",

International Politics, (54), No. 5, 2017: 637-658

Richmond, Oliver P, A Post-Liberal Peace, London: Routledge, 2012.

Richmond, Oliver P, Failed Statebuilding, Yale University Press, 2014.

Richmond, Oliver P. Peace Formation and Political Order, OUP, 2016.

Richmond, OP (2018). "The Green and the Cool", Mediterranean Politics.

Riley, P. "The Social Contract and Its Critics", in The Cambridge History of EighteenthCentury Political Thought, (Eds.) Mark Goldie and Robert Wokler. Vol. 4, Cambridge University Press, 2006.

Rosenau, James. "Toward an Ontology for Global Governance", in Martin Hewson and Timothy J. Sinclair (eds.), Approaches to Global Governance Theory, Albany, State University of New York Press, 1999. 
Sassen, S, Territory, Authority, Rights: From Medieval to Global Assemblages, Princeton University Press, 2006.

Scott, James C. Seeing Like a State: How Certain Schemes to Improve the Human Condition Have Failed, Yale University Press, 1998.

Smith, Anthony D. Nationalism and modernism : a critical survey of recent theories of nations and nationalism London: Routledge, 2001.

Smith, Linda Tuhiwai. Decolonizing Methodologies: Research and Indigenous Peoples, New York, NY: Zed Books, 1999/2012.

Spivak, Gayatri. "Can the subaltern speak?." In Cary Nelson \& Lawrence Grossberg (eds.), Marxism and the Interpretation of Culture, University of Illinois Press, 1988: 271-313.

Stepputat, Finn, and Jessica Larsen, "Global political ethnography: A methodological approach to studying global policy regimes", DIIS Working Paper, Copenhagen, 2015.

Tainter, JA. The Collapse of Complex Societies, Cambridge University Press, 1990.

Taylor, Astra "Afterword (s)", in Stephanie DeGooyer, Op. Cit. 2018.

Thaler, R, and C. Sunstein, Nudge, London: Penguin Books, 2008.

Turner, M. Peacebuilding as counterinsurgency in the occupied Palestinian territory. Review of International Studies, 41, No, 1, 2015: 73-98

UK Government The Belfast Agreement. UK Government Policy Papers, 10 April, 1998 https://www.gov.uk/government/publications/the-belfastagreement

UN. General Assembly Resolution, A/RES/70/262, 2016.

UN. Security Council Resolution S/RES/2282, 2016.

UN. "High-level Meeting on efforts undertaken and opportunities to strengthen the United Nations' work on peacebuilding and sustaining peace", 24 25 April, 2018.

UN. "Transforming our world: the 2030 Agenda for Sustainable Development", UN General Assembly A/RES/70/1, 25 ${ }^{\text {th }}$ September, 2015.

UNDP. Human Development Report, New York: UNDP, 2014.

R. J. Vincent, Nonintervention and International Order, Princeton University Press, 1974.

Visoka. G Shaping Peace in Kosovo: The Politics of Peacebuilding and Statehood.

Basingstoke, UK: Palgrave Macmillan, 2017.

Vucetic, Srdjan. The Anglosphere: A Genealogy of a Racialized Identity in International Relations. Stanford University Press, 2011.

Wallerstein, Immanuel. The Modern World-System, New York, Academic Press, 1974.

Weber, Max, Weber's Rationalism and Modern Society: New translations on Politics, Bureaucracy, and Social Stratification, (Edited and Translated by Tony Waters and Dagmar Waters), London: Palgrave, 2015.

Weber, Max. Economy and Society: An Outline of Interpretive Sociology. Berkley: U. California Press, 1978 [1922].

Wimmer, Andreas; Schiller, Nina Glick "Methodological Nationalism, the Social Sciences, and the Study of Migration: An Essay in Historical Epistemology". The International Migration Review. 37 No.2 (2003): 576-610.

Yaqing, Qin "Development of International Relations Theory in China", International Studies, (46) no. 1\&2, 2009: 185-201.

\footnotetext{
1 Oliver Richmond is a Professor of IR, Peace and Conflict Studies in the Department of Politics, University of Manchester, UK. He is also International Professor, College of International Studies, Kyung Hee University, Korea and a Visiting Professor at the University of Tromso. His publications include Peace Formation and Political Order in Conflict Affected Societies (Oxford University Press, 2016) and Failed Statebuilding (Yale University Press, 2014). He is editor of the Palgrave book series, Rethinking Peace and Conflict Studies, and coeditor of the Journal, Peacebuilding. Thanks to the audiences at the Millennium Conference at the LSE in autumn 2015, ECPR in Sicily in May 2016, and a workshop at ISA, Toronto, March, 2019.
} 
${ }^{2}$ Lewis, In Defense of Anthropology, 94.

${ }^{3}$ Bell, "What is Liberalism?", 684: Richmond, "A Post-Liberal Peace: Eirenism and the Everyday", 561.

${ }^{4}$ Richmond, "A Post-Liberal Peace: Eirenism and the Everyday", 571

${ }^{5}$ Mayall, James. Nationalism and international society.

${ }^{6}$ Reed and Harvey, "The New Science and the Old: Complexity and Realism in the Social Sciences", 365.

${ }^{7}$ Kant, Conflict of the Faculties: Pugh, "Peacekeeping and Critical Theory".

${ }^{8}$ Hallaq, The Impossible State, 102.

${ }^{9}$ KerLindsay, EU Accession and UN Peacemaking in Cyprus; Shaping Peace in Kosovo: The Politics of Peacebuilding and Statehood.

${ }^{10}$ Mayall, Nationalism and international society: Smith, Nationalism and modernism; Wimmer \& Glick,

"Methodological Nationalism, the Social Sciences, and the Study of Migration: An Essay in Historical

Epistemology".

${ }^{11}$ This can be seen in numerous Research Council calls in the UK, as well as in a more general appeal for more applied research to be carried out using large data sets or new technologies.

${ }^{12}$ Foucault, Discipline and Punish: the birth of a prison, 48.

${ }^{13}$ Richmond, The Transformation of Peace.

${ }^{14}$ Chandler, Bosnia: Faking Democracy After Dayton: Richmond and Franks, Liberal Peace Transitions; Caplan, A New Trusteeship?; Peo, "Peace through Democracy and Justice? Legacies and Lessons from the Case of Cambodia."

${ }^{15}$ Turner, "Peacebuilding as counterinsurgency in the occupied Palestinian territory": MacGinty, "Everyday peace: Bottom-up and local agency in conflict-affected societies".

${ }^{16}$ Hobbes, Leviathan, 150.

${ }^{17}$ Weber, Weber's Rationalism and Modern Society, 53.

${ }^{18}$ Arendt, On Violence, 44.

${ }^{19}$ Lukes, Power: A Radical View, 69.

${ }^{20}$ Hallaq, The Impossible State, 103.

${ }^{21}$ Pyykkonen, "Liberalism, Governmentality and Counter-Conduct", 20.

${ }^{22}$ Nixon, The crisis of governance in new subsistence states.

${ }^{23}$ Kaldor, New and Old Wars.

${ }^{24}$ Boutros Boutros-Ghali, An Agenda for Peace: Caplan, A New Trusteeship?

${ }^{25}$ ICISS, "The Responsibility to Protect: Report of the International Commission on Intervention and State Sovereignty".

${ }^{26}$ Richmond, Failed Statebuilding: Richmond and Franks, Liberal Peace Transitions; Paris, At War's End.

${ }^{27}$ Chandler, Bosnia: Faking Democracy After Dayton.

${ }^{28}$ Chandler, International Statebuilding: The Rise of Post-Liberal Governance.

${ }^{29}$ Joseph, "Governing Through Failure and Denial: The New Resilience Agenda", 1: Chandler, Resilience, the Governing of Complexity.

${ }^{30}$ Smith, Decolonizing Methodologies: Research and Indigenous Peoples.

${ }^{31}$ Behavioural Insights Team, Better Choices: Better Deals: Thaler and Sunstein, Nudge.

${ }^{32}$ Richmond, Peace Formation and Political Order.

${ }_{33}^{33}$ Millar, "Engaging Ethnographic Peace Research: Exploring an Approach".

${ }^{34}$ For an alternative approach that underlines the scalar, entangled, and intensively political nature of work within the everyday tradition, and contrary to uncritical methodological tendencies to ascribe it a 'subject' status see, Finn Stepputat and Jessica Larsen, "Global political ethnography: A methodological approach to studying global policy regimes".

${ }^{35}$ Richmond, "A Post-Liberal Peace: Eirenism and the Everyday", 558: see also, Richmond, A Post-Liberal

Peace; MacGinty, "Everyday peace: Bottom-up and local agency in conflict-affected societies", 548.

${ }^{36}$ Boege, "Hybrid Political Orders, Not Fragile States", 15: Richmond, A Post-Liberal Peace.

${ }^{37}$ Gilligan In a different voice: psychological theory and women's development: Marsha, "Gender, security and development" 63.

${ }^{38}$ UK Government The Belfast Agreement: Hall, "Incomplete Peace and Social Stagnation: Shortcomings of the Good Friday Agreement", 7.

${ }^{39}$ Branka, "The politics of everyday peace in Bosnia and Herzegovina and Northern Ireland", 67.

${ }^{40}$ Richmond, A Post-Liberal Peace 2016, concl.

${ }^{41}$ Habermas, The Structural Transformation of the Public Sphere.

${ }^{42}$ Habermas, Knowledge and Human Interests.

${ }^{43}$ Bhaskar, The Possibility of Naturalism, 34-5.

${ }^{44}$ Pyykkonen, "Liberalism, Governmentality and Counter-Conduct, 11.

${ }^{45}$ Visoka, Shaping Peace in Kosovo: The Politics of Peacebuilding and Statehood. 
${ }^{46}$ Hadjipavlou, "The Cyprus Conflict: Root Causes and Implications for Peacebuilding": Grenfell, "Making modernity in Timor-Leste": Richmond, A Post-Liberal Peace.

${ }^{47}$ Chakrabarty, Provincializing Europe: Postcolonial Thought and Historical Difference.

${ }^{48}$ Lensink, Structural adjustment in Sub-Saharan Africa.

49 Acemoglu and Robinson, Why Nations Fail, 44.

${ }^{50}$ Rawls, A Theory of Justice: Riley, "The Social Contract and Its Critics", 347-75

${ }^{51}$ Estlund, "Why not Epistocracy?", 53-69.

${ }^{52}$ Mitchell, Rule of Experts: Egypt, Techno-Politics, Modernity.

${ }^{53}$ Caplan, A New Trusteeship?

${ }^{54}$ Duffield, Post-Humanitarianism.

${ }^{55}$ Pogge, World Poverty and Human Rights: Hurrell, "Global Inequality and International Institutions".

${ }^{56}$ Chandler, Resilience, the Governing of Complexity.

${ }^{57}$ Confidential Official Source, UNDPKO, New York, March 2015.

${ }^{58}$ See Confidential Sources, UNDPK, New Work, February 2015 \& March 2016.

${ }^{59}$ Rosenau, "Toward an Ontology for Global Governance".

${ }^{60}$ Mayer and Acuto, "The Global Governance of Large Technical Systems", 675.

${ }^{61}$ James and Soguk, Globalization and Politics.

${ }^{62}$ Held, Global Covenant.

${ }^{63}$ Richmond, "The paradox of peace and power: Contamination or enablement?"

${ }^{64}$ Richmond, "Human rights and the development of a twenty-first century peace architecture: unintended consequences?", 60.

${ }^{65}$ Linklater, 'The achievements of critical theory': Linklater, 'The transformation of political community:

E.H.Carr, critical theory and international relations', 321.

${ }^{66}$ Grenfell, "Making modernity in Timor-Leste": Richmond, Failed Statebuilding.

${ }^{67}$ Comaroff and Comaroff, Theory from the South or, How Euro-America Is Evolving toward Africa.

${ }^{68}$ Mitchell, Rule of Experts: Egypt, Techno-Politics, Modernity.

${ }^{69}$ Acemoglu and Robinson, Why Nations Fail, 399.

${ }^{70}$ Pogge, World Poverty and Human Rights.

${ }^{71}$ Chandler, "Reconceptualising International Intervention: Statebuilding, 'Organic Processes' and the Limits of Causal Knowledge".

${ }^{72}$ Chandler, Ontopolitics and the Anthropocene, 209.

${ }^{73}$ Kant, Conflict of the Faculties.

${ }^{74}$ Foucault, "Questions of Method": Scott, Seeing Like a State: How Certain Schemes to Improve the Human Condition Have Failed.

75 Arendt, The Origins of Totalitarianism: DeGooyer, The Right to Have Rights, 4: Taylor, "Afterword (s)", 106.

${ }^{76}$ Duffield, Global Governance and the New Wars: The Merging of Development and Security.

${ }^{77}$ Pattberg and Widerberg, "Theorising Global Environmental Governance", 685.

78 Thanks to Sandra Pogodda for this point.

${ }^{79}$ Vucetic, The Anglosphere: A Genealogy of a Racialized Identity in International Relations.

${ }^{80}$ For example, see the UK Government's Stabilisation Unit: https://www.gov.uk/government/organisations/stabilisation-unit

${ }^{81}$ Sassen, Territory, Authority, Rights: From Medieval to Global Assemblages, 365.

${ }^{82}$ UN, "Transforming our world: the 2030 Agenda for Sustainable Development", 33 \& 40): UNDP, Human Development Report.

${ }^{83}$ Kaldor, Global Civil Society: An Answer to War: Latour, Reassembling the Social: An Introduction to ActorNetwork-Theory.

${ }^{84}$ Chandler, 'Beyond neoliberalism: resilience, the new art of governing complexity'.

${ }^{85}$ Wallerstein, The Modern World-System, 347-57.

${ }^{86}$ Pogodda and Richmond, "Palestinian unity and everyday state formation: subaltern 'ungovernmentality' versus elite interests", 890 .

${ }^{87}$ Coole and Frost, New Materialisms: Ontology, Agency, and Politics.

${ }^{88}$ Kennedy, A World of Struggle, 7.

${ }^{89}$ Chomsky, "The Responsibility of Intellectuals".

${ }^{90}$ Spivak, "Can the subaltern speak?", 271-313.

${ }^{91}$ Yaqing, "Development of International Relations Theory in China", 185.

${ }^{92}$ Vincent Non intervention and International Order: Finnemore, The Purpose of Intervention, Changing Beliefs about the Use of Force. 
${ }^{93}$ UN, "Transforming our world: the 2030 Agenda for Sustainable Development": UN General Assembly Resolution A/RES/70/262;UN Security Council Resolution S/RES/2282; UN, "High-level Meeting on efforts undertaken and opportunities to strengthen the United Nations' work on peacebuilding and sustaining peace".

${ }^{94}$ Tainter, The Collapse of Complex Societies, 42.

${ }^{95}$ Reus-Smit, Individual Rights and the Making of the International System, 5.

${ }^{96}$ Foucault, The Birth of Biopolitics, 37.

${ }^{97}$ Kohn, "Postcolonialism and global justice".

${ }^{98}$ Connolly, Facing the Planetary, 125. 